\title{
Questions about Fiscal Policy: Implications from the Financial Crisis of 2008-2009
}

\author{
N. Gregory Mankiw
}

\begin{abstract}
This article is a modified version of remarks given at the Federal Reserve Bank of Philadelphia's policy forum "Policy Lessons from the Economic and Financial Crisis," December 4, 2009. The presentation was made during a panel discussion that also included James Bullard and John Taylor.
\end{abstract}

Federal Reserve Bank of St. Louis Review, May/June 2010, 92(3), pp. 177-83.

\section{EVALUATING FISCAL POLICY}

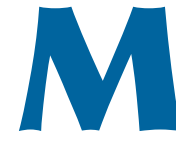

y objective here is to offer some reflections about recent fiscal policy. But I want to begin with an example, and I hope a useful analogy, about medicine.

Imagine you are a physician and a patient comes to you with some adverse symptoms. He's in pretty bad shape. You have never treated a condition quite like this before, and the causes of his ailments are not at all clear. You remember reading about a similar case in medical school, and so you try to recall as much as possible and come up with a theory as to what is making this patient sick. Then you choose the medicine that you hope will make the patient better.

What you would prefer to do is run a controlled experiment. You'd like to assemble 100 patients with similar conditions, give 50 of them the medicine you think might work and 50 of them a placebo, and then see whether the patients receiving the medicine recover. But you do not have 100 patients; you have only one. What do you do?

Well, you take your best shot. You decide what you believe to be the most likely cause of the patient's trouble and the most likely remedy to improve his health. Then you administer the medicine.
But the patient returns a few weeks later, and his symptoms are worse. What do you conclude? You might decide that you gave him the wrong medicine. Or you might decide that the patient is even sicker than you thought he was when he first came in and that you should increase the dosage.

If you consider the epistemological question, you realize that either of those conclusions is possible. The patient could have been sicker than you realized, and maybe you do have the right medicine. Or maybe you're on the wrong track completely. Because you have only one patient, you don't have any way to conduct that controlled experiment. So, you can't be sure.

This analogy describes the problem facing the Obama administration right now. They entered office when our economy was very sick. They concluded that, if they did nothing, the unemployment rate would reach 9 percent. (That was their forecast in the documents they released shortly after the election.) But they had a plan to stimulate the economy by spending a great deal of money, and with that stimulus-according to their estimates-the unemployment rate would not exceed 8 percent.

At the time of this writing, unemployment is more than 10 percent. So what do we make of that?

N. Gregory Mankiw is the Robert M. Beren Professor of Economics at Harvard University.

(C) 2010, The Federal Reserve Bank of St. Louis. The views expressed in this article are those of the author(s) and do not necessarily reflect the views of the Federal Reserve System, the Board of Governors, or the regional Federal Reserve Banks. Articles may be reprinted, reproduced, published, distributed, displayed, and transmitted in their entirety if copyright notice, author name(s), and full citation are included. Abstracts, synopses, and other derivative works may be made only with prior written permission of the Federal Reserve Bank of St. Louis. 
The administration has concluded that the patient must be sicker than they thought.

I should emphasize that the Obama administration has been guided by a standard theory in the economics profession-textbook Keynesian theory, to be specific. They thought that, because of the credit crisis, people were not able to obtain loans; and, because people were not able to obtain loans, there was insufficient aggregate demand. Looking to the standard textbook theory that fiscal policy can prop up aggregate demand, they implemented their stimulus plan.

In the forecast the administration used to describe the effects of the stimulus, they provided the multipliers that guided their actions. Their government-purchases multiplier was 1.57, and their tax multiplier was 0.99. Because 1.57 is larger than 0.99 , they concluded it was better to spend money than to cut taxes. They obtained those numbers from a simulation of a standard macroeconometric model-the kind of model people have been building for years. It is the kind of model that Robert Lucas famously critiqued, but many economists have continued to build such models and use them for policy analysis and forecasting.

The question, ultimately, is whether the model is right, whether it accurately describes how the world works. If you could be sure the model was right-if God told you, "Yes, this model of the economy that you're simulating, it is truth"then, when your stimulus plan was followed by 10 percent unemployment, you would know what to conclude: The patient was sicker than you thought, because, after all, the stimulus worked; my model said so. And if the stimulus worked, then unemployment would surely have been 11 percent if not for the stimulus. That is the position the administration is taking now.

Of course, we do not know if it is the right model. Macroeconomists have to be extremely humble. There is a lot we do not know.

I teach the Principles of Economics course at Harvard. It is a full-year course, and I start with what we economists are confident is true and then move on to material that is less and less certain as the year goes on. We look first at supply and demand, the theory of comparative advantage, profit maximization, marginal revenue equals marginal cost-the premises we agree on. Eventually, as the course goes on, we move to macroeconomics. We examine classical monetary theory, growth theory, and at the very end of the course the theory of business cycles, which is the topic we understand least of all.

I am actually a believer in Keynesian theory; much of my research is in that field. But even as a believer in many aspects of Keynesian theory, I appreciate that you cannot approach this subject matter without showing some humility about what we, as economists, can truly be confident about.

In an attempt to "know" as much as possible, the Obama administration is compiling data to measure the effect of the stimulus. (See www.recovery.gov, where you can find state-level job creation "data" reported to two decimals of accuracy!) This effort is, I think, the least credible part of the whole endeavor. The reporting errors are tremendous because no one accurately fills out these questionnaires with the true number of jobs they are creating.

My favorite story is about a firm that was selling boots to the U.S. Army; their managers decided that they were creating one job for every pair of boots they sold, because, after all, a soldier could not go to work without a pair of boots. This anecdote received some attention only because a reporter looked through the job-creation numbers and discovered that this particular organization was the most efficient job creator in the country: For every $\$ 100$ spent, they created a job!

Putting aside these absurd reporting errors, even if the reporting were perfectly correct, the whole activity still makes no sense. When we talk about the effects of government purchases on aggregate demand, and therefore on job creation, there is an array of general equilibrium effects ("knock-on effects") that are tremendously important-some positive, some negative. These jobcreation surveys cannot possibly capture these effects.

The positive effects are those that arise from the conventional Keynesian fiscal-policy multipliers. Higher government spending leads to higher income, which causes higher consumption and therefore higher income yet again. But 
recovery.gov cannot possibly account for all the multiplier effects involved.

There are also growth-retarding effects associated with government spending. If people observe substantial government debt being issued, they may anticipate higher future taxes and therefore cut back on their current consumption. These retarding effects are also absent from recovery.gov. In addition, there are crowding-out effects working through financial markets. Increased government borrowing drives up long-term interest rates and reduces spending today. But, given its limited scope, recovery.gov cannot take that into account either.

So even if the administration could accurately measure what they set out to measure, the data they created would not accurately describe, from a macroeconomist's standpoint, how many jobs were created.

\section{TAXING LESS VERSUS SPENDING MORE}

The larger question for me is this: Would we have been better off focusing on the tax side of fiscal policy rather than on the government spending side? I think there are several issues here to consider.

The first question is whether the government can spend large sums of money quickly and wisely. To consider the question, I'll offer a personal story. I live in a suburb of Boston called Wellesley. Coincidentally, my town has been debating building a new high school, which is now being constructed just a few blocks from where I live. The project is creating many jobs and, in fact, seems to have been planned and implemented in an intelligent and prudent way. Participating in such a process makes you realize how much time it takes to accomplish something this substantial. The town spent many months debating whether to build a new high school or renovate the old high school. Once they decided that issue, they spent many months designing the new school and determining everything they wanted in a school. They spent many more months selecting the site to build on and which houses to take over to obtain the land. It was a years-long process.
Now, what if someone had provided all the funds for a new Wellesley high school but demanded that it be built immediately? Presumably, quality would have been sacrificed for speed. It would have been built more quickly because, presumably, if people are told they have to spend money immediately, they will find some way to do it. But in such an environment- town planning or national fiscal policy-you wonder whether money can be spent both quickly and wisely.

The second question, which is more academic in nature, is about the size of the relevant multipliers. The textbook Keynesian model tells us that government purchases multipliers are larger than tax multipliers. And, again, the Obama administration's economic team consulted these standard models in reaching their conclusions. However, there is a variety of evidence that calls those conclusions into question.

Somewhat ironically, one piece of evidence against this preference for government spending over cutting taxes comes from Christina Romer, the current chair of the Council of Economic Advisors for President Obama. About six months before she took that job, she wrote a paper with her husband David Romer about the impact of tax policy on the economy (Romer and Romer, 2009). The Romers wanted to measure the influence of taxes on gross domestic product (GDP), ensuring that they identified the exogenous movements in taxes and separating those from the endogenous movements, where taxes were responding directly to the economy.

Their conclusion was that the tax multiplier was 3-that is, every dollar spent on tax cuts would raise GDP by $\$ 3$. That is roughly three times the size that the Obama administration assumed with their policy simulations. To be clear, I don't blame the Obama administration for relying on more conventional multiplier estimates. Nor is it reasonable to assume that simply because they appointed Christina Romer to chair the Council that they must use her research in measuring the multiplier. But the Romers' research does suggest that conventional results about tax policy on GDP are understated.

Of course, it could be the case-and this is in fact the Obama administration's interpretation- 
that all multipliers may be larger than previously measured. Fiscal policy may be so potent that, if the tax multiplier is 3 , the government's spending multiplier might be 4 or 5 . The Romers did not analyze government spending multipliers in their recent study, but only tax multipliers. Clearly, it is still an open question. Yet, there has been a variety of research on government spending multipliers using techniques similar to those used by the Romers. This research has tried to uncover exogenous movements in government spending, and no one finds government spending multipliers to be especially large.

The best work on this topic, I think, is from Valerie Ramey at the University of California at San Diego (Ramey, 2009). Ramey finds government spending multipliers of about 1.4, which is not very different from what the Obama administration assumed, but much smaller than the Romers found for taxes. Similarly, Andrew Mountford and Harold Uhlig, using vector autoregression techniques, have also found that taxes have a more potent effect than government spending (Mountford and Uhlig, 2009).

The piece of evidence I want to draw your attention to in particular, though, is some very recent work by my colleagues Alberto Alesina and Silvia Ardagna at Harvard. They used data from the Organisation for Economic Co-operation and Development (OECD) to identify every major fiscal stimulus in those countries (Alesina and Ardagna, 2009). They then separated out the successful policies-those that in fact were followed by robust economic growth-from the unsuccessful ones and compared their characteristics. They found that the successful stimulus packages cut business and income taxes and the unsuccessful stimulus packages increased government spending and transfer payments.

The data in the Alesina-Ardagna study are mostly European, with only a small portion from the United States. But they lead to conclusions that are very similar to those from Mountford and Uhlig's work using U.S. data in vector autoregressions. These conclusions are also consistent with the work from Ramey and the Romers that looks at the historical record to identify multipliers. A growing body of evidence seems to suggest that taxes may be a better tool for fiscal stimulus than conventional models have indicated.

\section{TAXES AS FISCAL POLICY TOOL}

What, then, is behind these conclusions that taxes have a more potent effect on the economy than spending? The answer is not clear-cut, but it is easy to speculate why this could be true. Most obviously, there are effects on the supply side. Tax rates influence work incentives, for instance. But even if you believe that aggregate demand drives the economy in the short run, as many Keynesians do, you might consider that taxes affect aggregate demand in ways that are not included in the textbook Keynesian model.

When we change taxes, we typically do not just write checks to taxpayers. Usually, we change marginal tax rates: We change corporate income taxes, change personal income taxes, and maybe even institute an investment tax credit. These measures have more complicated and nuanced effects on aggregate demand than what the textbook Keynesian model assumes. It is not simply a change in cash flow; it is actually a change in marginal incentives and can even be a direct encouragement to spend. One example is creating tax incentives to invest.

The Cash for Clunkers program involved that type of incentive. I was not much in favor of that specific micromanagement of how people should spend their money. Nonetheless, the fact that people responded to a tax incentive like Cash for Clunkers does suggest that a more comprehensive program (such as an investment tax credit) might have stimulated spending even more broadly.

Many other tax policies have been discussed recently. One in particular has received some attention: a tax cut for new hires. As many have pointed out, the premise behind this policy is that, because unemployment is so high even as we proceed through the recovery, we should create incentives for businesses to hire new workers.

There is a case to be made for a payroll tax cut. In fact, at one point I advocated an immediate and permanent payroll tax cut financed by a gradual increase in gasoline taxes over time. But 
a tax cut for new hires is probably not a good idea. The basic problem is that we do not know how to properly define-or enforce a definition of-a "new hire." Presumably, we do not want a business to hire Peter by firing Paul and call Peter a new hire; that would cause a great deal of inefficient churning in the labor force.

Usually, when tax credits for new hires are proposed, the idea is to establish some baseline employment and give credit to businesses that meet or exceed that baseline. But even establishing a baseline has its limitations. Consider an industry hit particularly hard by a recession-say, construction-in which employment is well below the baseline established for the tax breaks. Because a few new hires would not make these firms eligible for the tax breaks, these firms would have no marginal incentive to hire additional workers. Conversely, industries that have been expanding would be rewarded for hires they may have made even without the tax incentives. This policy, then, would likely create tremendous disparities across industries that could be both inequitable and inefficient.

There is also the problem of new firms. New firms are always a large part of economic growth and the overall dynamics of the economy. By definition, all employees of a new firm are "new hires." But if there is a tax credit for new hires at new firms, then that provides all sorts of incentives for existing firms to, say, lay off the janitorial staff and hire instead an independent janitorial contractor that just started up as a new firm. The bottom line is that it is very difficult to implement a tax credit for new hires, attractive as the idea seems at first.

\section{THE LONG-RUN FISCAL SITUATION AND THE HEALTHCARE CHALLENGE}

Any discussion of fiscal policy has to be couched in terms of the long-run fiscal picture. I know that some economists have made the argument that we should not be concerned about the long-run fiscal picture when we consider shortrun fiscal policy: Once the economy begins to grow again, they contend, tax revenue will flow in and the longer-term fiscal picture will be improved. That would be true if these policy multipliers were very large, but they are probably not so large, in my judgment, that we can ignore the long-run problems created by short-run policies.

We now face a very dire long-run fiscal picture, which is being driven by a couple of factors. One is the aging of the population, with the first wave of Baby Boomers beginning to retire. I explain this scenario to my students at Harvard this way: "My generation has promised ourselves generous retirement benefits in the form of Social Security and Medicare, and we promise you're going to pay for it. How do you feel about that?"

The bills for those benefits are large partly because of aging and partly because of higher healthcare costs. The latter is one of the motivations, allegedly, for the current healthcare legislation. I am personally skeptical that this legislation will reduce healthcare spending substantiallyif at all. So on that score, we are not making true progress on the long-run fiscal picture. To address the issue, I would raise the age of eligibility for Social Security and Medicare. Economists seem to like this idea, but in polls of the general public it is much less popular, so I don't expect this idea to be implemented.

I should note that I am not optimistic that any proposed measure will reduce healthcare costs significantly. People talk about "bending the curve" and squeezing out waste, fraud, abuse, and so on. My reading of the evidence brings me to the conclusion that healthcare is growing more expensive over time mainly because technologies are improving. That is a good thing, but it is also expensive, and so we must find a way to pay for it. I am not sure what the right answer is, but I don't think that rooting out waste, fraud, and abuse is going to save much money. I am sure there is some waste, fraud, and abuse-there is in all systems-but it is not likely a primary driver of healthcare costs.

One of the classic hypothetical questions economists ask when referring to healthcare costs is, "Would you rather go back to 1950s medical care and 1950s prices?" If that option were offered at your place of work, my guess is that you would not take it. What that means is, in some real sense, 
healthcare is cheaper today if you adjust prices properly to account for quality improvements. A dollar of healthcare today has more value than a dollar of healthcare in 1950.

I posed another hypothetical question in a New York Times column in September 2009: Imagine a Dorian Gray pill has been invented and that taking the pill every day will keep you the same age for as long as you take the pill. It is perfect healthcare: You would not age or become sick or die. The problem is that these pills are expensive-let's say, it costs $\$ 1,000$ to manufacture each daily dose. Again, it is perfect healthcare but at a very, very expensive price. How would we, as a society, deal with that? I don't think we have the answer to that question, but in some sense we are moving in that direction already, with health technology continually improving but also becoming more and more expensive. As a society, we have not figured out how we are going to eventually say no to people or have people say no for themselves.

\section{THE COMING VALUE-ADDED TAX?}

I have my own normative conclusions about addressing some of these problems, such as raising the retirement age. What I believe is more likely to occur, however, is that taxes will be raised to very high levels. I thought it was very interesting when, in late 2009, Nancy Pelosi suggested the idea of a value-added tax.

A value-added tax (VAT) is an efficient tax from an economic standpoint. It is basically a flat consumption tax, so it tends to be an efficient way to raise revenue. But it is also a fairly well hidden tax, and there is some debate among proponents and opponents about that aspect.
In particular, people look at European countries and see the connection between their large governments and their VATs and conclude that the problem with the VAT is that it makes government grow too much. That is one possibility. Another possibility is that governments grow, and, when they do so, they look for ways to raise revenue efficiently. In many cases, they turn to a VAT. My guess is that the latter is probably the correct direction of causation and that it is also probably the direction in which we're heading: larger government and higher taxes. If we use the tax system we have now, though, the revenue raised will likely fall short; hence, we are probably going to move in the direction of a VAT.

Such a large change in our tax policy would inevitably incite comparisons with Europe. There is a literature about how and why the European workforce differs from the American workforcespecifically, why Europeans enjoy spending more time at the café than Americans do and why we work harder than they do. There are many hypotheses out there. Olivier Blanchard says that it stems from cultural tastes (Blanchard, 2004): Europeans have more joie de vivre than Americans, and therefore they want to enjoy their high productivity by spending more time enjoying leisure. My colleagues Alberto Alesina and Ed Glaeser, as well as Bruce Sacerdote from Dartmouth (Alesina, Glaeser, and Sacerdote, 2005), say that it is the presence and scope of powerful labor unions in Europe that have negotiated shorter workweeks, more vacation days, and so on. But Ed Prescott tells us it is the high tax rates in Europe (Prescott, 2004), and I actually find this argument the most compelling. What that means is, if we are heading toward higher tax rates, my children will enjoy a lot more leisure than I do. 


\section{REFERENCES}

Alesina, Alberto and Ardagna, Silvia. "Large Changes in Fiscal Policy: Taxes versus Spending." Working paper, Harvard University, October 2009.

Alesina, Alberto; Glaeser, Edward L. and Sacerdote, Bruce. "Work and Leisure in the United States and Europe: Why So Different?” NBER Macroeconomics Annual. Volume 20. Chicago: University of Chicago Press, 2005, pp. 1-64.

Blanchard, Olivier. “The Economic Future of Europe.” Journal of Economic Perspectives, Fall 2004, 18(4), pp. 3-26.

Mountford, Andrew and Uhlig, Harald. "What Are the Effects of Fiscal Policy Shocks?” NBER Working Paper No. 14551, National Bureau of Economic Research, December 2008.

Prescott, Edward C. “Why Do Americans Work So Much More than Europeans?” Federal Reserve Bank of Minneapolis Quarterly Review, July 2004, 28(1), pp. 2-13; http://minneapolisfed.org/research/qr/qr2811.pdf.

Ramey, Valerie. "Identifying Government Spending Shocks: It's All in the Timing.” Working paper, University of California at San Diego; NBER Working Paper No. 15464, National Bureau of Economic Research, October 2009.

Romer, Christina D. and Romer, David H. "The Macroeconomic Effects of Tax Changes: Estimates Based on a New Measure of Fiscal Shocks.” Working paper, University of California at Berkeley, April 2009 (forthcoming in American Economic Review); http://emlab.berkeley.edu/users/dromer/papers/RomerandRomer.pdf. 
